\title{
Labor Costs and Investments in Human Capital
}

First Draft: July 1998

Current Draft: November 1999

\author{
Marta Ballester \\ University of Malaga \\ Joshua Livnat \\ New York University
}

\author{
Nishi Sinha \\ New York University
}

This study examines the disclosure of labor-related costs by US firms, and estimates the proportion of these costs that are valued as an asset (human capital) by the market. Separate identification of labor-related costs in US financial reports is voluntary, and is made consistently only by about $10 \%$ of all US Compustat firms. The probability of disclosure is found to be positively related to firm size, labor intensity and membership in regulated industries and is inversely related to industry concentration.

Using a modification of Ohlson's (1995) framework the study finds that on average about $16 \%$ of all such costs are valued by the market as an investment in human capital, and that this human capital asset amortizes at a rate of about $34 \%$ per year. Further, the human capital asset averages about $5 \%$ of the total market value of the firm and accounts for about $16 \%$ of the difference between market and book value. The ratio of the human capital asset to market value is found to be positively related to average salary paid to employees, operating uncertainty, and the ratio of labor expenses to sales, but inversely related to the firm's size.

This paper can be downloaded from the Social Science Research Network Electronic Paper Collection: http://papers.ssrn.com/paper.taf?abstract_id=218893 


\title{
Labor Costs and Investments in Human Capital
}

\author{
Marta Ballester \\ Department of Accounting and Finance \\ Faculty of Business and Economics \\ University of Malaga \\ Campus EL Ejido \\ 29071 Malaga \\ Spain \\ (011-34-5-2131239) \\ mballester@uma.es \\ Joshua Livnat* and Nishi Sinha** \\ Department of Accounting \\ Leonard N. Stern School of Business Administration \\ New York University \\ 40 West $4^{\text {th }}$ St. \\ NY, NY 10012 \\ *(212) 998-0022 \\ jlivnat@stern.nyu.edu \\ **(212) 998-0026 \\ nsinha@stern.nyu.edu
}

First Draft: July 1998

Current Draft: November 1999 


\title{
Labor Costs and Investments in Human Capital
}

\begin{abstract}
This study examines the disclosure of labor-related costs by US firms, and estimates the proportion of these costs that are valued as an asset (human capital) by the market. Separate identification of labor-related costs in US financial reports is voluntary, and is made consistently only by about $10 \%$ of all US Compustat firms. The probability of disclosure is found to be positively related to firm size, labor intensity and membership in regulated industries and is inversely related to industry concentration.

Using a modification of Ohlson's (1995) framework the study finds that on average about $16 \%$ of all such costs are valued by the market as an investment in human capital, and that this human capital asset amortizes at a rate of about 34\% per year. Further, the human capital asset averages about $5 \%$ of the total market value of the firm and accounts for about $16 \%$ of the difference between market and book value. The ratio of the human capital asset to market value is found to be positively related to average salary paid to employees, operating uncertainty, and the ratio of labor expenses to sales, but inversely related to the firm's size.
\end{abstract}




\section{Labor Costs and Investments in Human Capital}

\section{Introduction}

As the US economy completes the transition from an industrial to a service and knowledge-based economy, the asset-mix in firms' portfolios reflects this change. Most firms, including manufacturing firms, have seen a growing emphasis on non-physical assets over physical assets. These non-physical assets, though vital to most modern firms, pose special problems in terms of measurement and valuation. One of the most fundamental non-physical assets for all firms is their human capital.

This paper considers the market valuation of firms' labor-related expenditures. Although U.S. GAAP does not require labor costs to be identified separately, some firms voluntarily disclose these costs in their financial reports. The extant financial reporting practice is to expense all labor-related costs in the current period, under the assumption that all expenditures for labor are for current period's consumption. However, if some portion of this expenditure represents an investment in human capital, the benefits from which will accrue in future periods, reported earnings and asset values for the current period are understated.

We use Ohlson's (1995) valuation framework to address two issues. First, we estimate the proportion of a firm's total labor expenditure that the market views as an investment in human capital versus the part that the market values as an expense. Second, for that portion of labor expenditure that the market views as an investment, we estimate the economic amortization rate for the asset human capital.

Our study differs from prior studies on the market valuation of various intangible assets (such as advertising, $\mathrm{R} \& \mathrm{D}$, or software expenditures) in some key respects. One, unlike the expenditure items in the above-mentioned studies, separate disclosure of labor cost data is not 
required by GAAP. As a result, when firms do report this data, it is on a voluntary basis. This selective disclosure of labor cost data forces us to consider the voluntary disclosure incentives of disclosing firms and to make appropriate adjustments in the market valuation estimates of labor expenditure. Another key feature of our study is that it uses time-series data about firms' market-to-book ratios, earnings, and labor costs. Most other studies essentially estimate the average value of certain intangibles through cross-sectional analysis.

Our results show that larger firms and firms in regulated industries are more likely to report labor-related costs voluntarily, perhaps due to the greater political costs experienced by these firms, and their desire to reduce such costs by portraying themselves as good employers. We also find that firms in more concentrated industries are less likely to disclose labor-related costs, presumably because firms in such industries attempt to retain their competitive position by lower levels of disclosure. Finally, we find that firms in labor-intensive industries tend to disclose labor-related costs more often than firms in less labor-intensive industries, presumably because such costs represent a more significant proportion of all costs.

For the sample of firms with consistent disclosure of labor-related costs, the study finds that about $16 \%$ of all such costs represent an investment in human capital, and that this human capital asset declines at a rate of about $34 \%$ per year. Even for firms that chose to disclose labor costs voluntarily, human capital asset averages only about $5 \%$ of the firm's market value, although it explains about $15 \%$ of the difference between market and book values of these firms. Further, the ratio of the human capital asset to market value is positively related to labor cost intensity (the ratio of labor expenses to sales), average salary and operating uncertainty, and is inversely related to size (total assets), probably because large firms need to invest less to maintain their employees' skills, and externalize these costs by hiring trained employees. 
The next section discusses the disclosure of labor costs, and the nature of the data used in the study. The third section studies the motives for voluntary disclosure of labor costs. The fourth section develops the theoretical valuation of the investment in human capital and provides estimates for the investment and amortization rate. It also tests the relationship of these parameters with various variables. The last section summarizes the study and offers future avenues for research.

\section{Disclosure of Labor Cost Data}

U.S. firms usually aggregate labor-related expenses in cost of goods sold, and/or in selling, general and administrative expenses. Although generally accepted accounting principles do not require the separate disclosure of labor-related expenses, a portion of U.S. firms voluntarily report these costs separately. ${ }^{1}$ Our review of Compustat data from 1978-1997 showed that while most firms never report this data, a small fraction (less than $10 \%$ ) reported it consistently every year during that period. For the remaining firms (about 20-30\%), this data were available in some, but not all, of the examined years.

"Labor and related expenses" appears as data item number 42 on the Compustat Annual Industrial and Research Files and represents employees' wages and benefits allocated to continuing operations. Besides salaries and wages, this item may also include incentive compensation, pension costs and other benefits plans, payroll taxes, and profit sharing. Typically, when firms disclose this information voluntarily they do not explain which items are included in the disclosure. Consequently, cross-sectional comparisons of labor-related expenses are tentative, and we resort to time-series analysis in this study. 
For firms that have consistently disclosed labor cost data over the period 1978-1997, preliminary analysis revealed the following trends in labor related expenses, as depicted in Figure 1. Average labor expenses have increased sharply and steadily over these 20 years, more than doubling from about \$563 million in 1978 to about \$1655 million in 1997 (without adjusting for inflation), an annual growth rate of about 5.8\%. Similarly, the average sales per employee increased over this 20 -year period from $\$ 86,500$ in 1978 to $\$ 281,600$ in 1997 , or an annual growth rate of about $6.4 \%$. We also find that average labor expense per dollar of sales declined steadily after an initial rise in the late ' 70 's- early ' 80 's. This initial rise corresponded to a period of recession for the U.S. economy, when sales declined sharply but firms presumably were unable to reduce their labor costs commensurably. The data in Figure 1 imply that the consistently disclosing firms benefited from improvement in labor efficiency and/or a shift in production parameters away from labor to non-labor inputs.

The valuation of labor costs, and in particular, the proportion that can be considered an investment in human capital, can only be performed for firms that voluntarily disclose laborrelated expenses. However, the results we obtain may not be generalizable to the rest of the population if disclosing firms are systematically different from non-disclosing firms. Therefore, Table 1 compares some key variables for two groups of firms - those that consistently disclosed labor cost data for the period 1978-1997 ("disclosing firms") versus those firms that never provided these data during the same time period ("non-disclosing firms"). ${ }^{2}$ As can be seen from the table, the two samples are significantly different in several respects in $1996 .^{3}$

\footnotetext{
${ }^{1}$ In some countries outside of the U.S., e.g. Spain, firms are required to separately disclose labor cost data in their financial reports. However, to avoid the well-known problems related to international comparisons of financial information, we restrict the sample to U.S. firms only.

${ }_{2}^{2}$ The following Probit analysis will also include firms that have provided data for some but not all of the years.

${ }^{3}$ Results for other years are very similar to those reported in Table 1. For brevity, they are omitted here.
} 
We find that disclosing firms are larger than non-disclosing firms, with significantly larger total assets, sales, and number of employees. Disclosing firms also have a higher Return on Equity (ROE) and lower standard deviation of ROE (over the five-year period ending in 1996) than non-disclosing firms, signifying greater profitability and stability for these firms. As expected, disclosing firms are also more likely to be in regulated industries. Finally, disclosing firms have accessed the capital market less frequently than their non-disclosing counterparts in the 10-year period ending in 1996.

The Revenue per Employee (REV/EMP) may be considered a rough indicator of labor intensity of a firm's operations, with more labor intensive firms having a lower revenue per employee and more capital intensive firms a higher revenue per employee. Disclosing firms have a lower mean REV/EMP but a higher median REV/EMP than non-disclosing firms, indicating that the median disclosing firm is less labor intensive. Disclosing firms are also growing at a slower pace than non-disclosing firms.

Since disclosing firms are significantly different from non-disclosing firms in several important attributes, we first explore potential explanations for the voluntary disclosure of laborrelated expenses.

\section{Voluntary Disclosure of Labor Costs}

In general, prior analytical and empirical analysis suggests that firms' voluntary disclosure choices are determined by both competitive and capital market concerns. Clarkson et al (1992), Clarkson et al (1995), Frankel et al (1995) and Lev and Kasznik (1995) have documented that the magnitude of voluntary disclosure of prospective information is positively related to a firm's size, profitability, stability, and financing needs, and is inversely related to the degree of 
competition in the given firm's industry (see also Darrough and Stoughton (1990), Wagenhofer (1990)). Many of the factors that prompt firms to disclose prospective information such as earnings forecasts, may also prompt them to disclose more detailed information. Further, to the extent that more detailed current information is correlated with future values of firms, the same factors that affect voluntary disclosure of prospective information may affect the voluntary disclosure of more detailed information.

For instance, it is argued that larger firms may be subject to higher political costs and may try to alleviate these costs by providing more detailed financial data. Moreover, as Lang and Lundholm (1993) suggest, larger firms may experience economies of scale in terms of the preparation costs of financial reports and may therefore be willing to provide additional data. Therefore, we expect a positive relation between the probability of labor cost disclosure and size. Competitive concerns may also influence a firm's choice of aggregation in its financial reports. In general, one way of preserving competitive edge is to reveal minimal information publicly. Therefore, we expect to find a lower probability of disclosure in more concentrated (and less competitive) industries.

Firms in some regulated industries may be required to provide labor-related information. Alternatively, they may be more willing to reveal additional information since they operate in relatively protected industries where competitive concerns are not that acute. ${ }^{4}$ The positive relationship between regulation and disclosure probability is strengthened by the political benefits that regulated firms may obtain from highlighting the extent of employment in their sectors.

\footnotetext{
${ }^{4}$ Note the significantly high correlation between the variables REGULATED and CONC in Table 1B.
} 
Frankel et al (1995) document that firms that access the capital market for financing needs are more likely to provide prospective information (i.e., earnings forecasts) more frequently, perhaps in an attempt to lower their cost of capital. Botosan (1997) provides empirical support for the inverse relationship between voluntary disclosure levels in annual reports and cost of equity capital for firms with low analyst following. ${ }^{5}$ Thus, firms with greater need for capital, and labor costs that are a significant part of total expenditures, are more likely to identify labor costs separately in an attempt to favorably impact their cost of capital.

Prior literature on earnings forecasts has also found a positive relationship between a firm's willingness to disclose information and its profitability and stability. Following the same arguments, we hypothesize a positive relationship between the probability of disclosing labor costs and a firm's profitability and stability.

Finally, there may be motivating factors specific to labor costs themselves that prompt firms to disclose labor cost information. For instance, firms in which labor costs are a major component of their total expenditures may want to identify this component separately. This is likely to be the case for more labor intensive firms. We therefore posit a positive relationship between labor intensity and the probability of labor cost disclosures. ${ }^{6}$

The preceding discussion leads us to the following hypotheses regarding the voluntary disclosure of labor costs by firms. We separate the hypotheses into two parts to emphasize that while the first set of factors affects the provision of more detailed data in general, the second set specifically addresses the provision of labor cost data.

\footnotetext{
5 Botosan does not find any association between the two variables for firms with a high analyst following. 6 The degree to which the labor force is unionized may be another labor-specific factor that prompts firms to be more forthcoming with such detailed labor cost information.
} 
Hypothesis 1a: The probability of disclosure of labor costs is increasing in the size, profitability, stability, and financing needs of the firm, and is inversely related to the degree of competition in the firm's industry.

Hypothesis 1b: More labor intensive firms are more likely to disclose labor cost data.

As is common in the literature, we test the hypotheses using Probit analysis. However, in our case we actually have three levels of voluntary disclosure - consistent disclosure over all 20 years during 1978-1997, disclosure in a portion of this period, and no disclosure of labor costs for any year during the period. Consequently, the dependent variable DISC is set to 1 if the firm disclosed labor costs in all years during 1978-1997, 0 if labor costs were disclosed in some but not all of the years, and -1 if labor costs were never disclosed during this time period. We report below results when all three groups are separated in the analysis, and when the full and partial disclosure firms (DISC $=0$ and 1 ) are aggregated into one group.

The independent variables in the Probit analysis are as follows. Firm's size is measured by the log of sales (LSALES). The degree of competition in an industry is measured by the 4firm concentration ratio, CONC. This is the ratio of revenues of the largest four firms in a fourdigit SIC industry to total industry revenues. The higher is this ratio, the more concentrated (and, therefore, less competitive) is the industry.

The profitability of a firm is measured in terms of its Return on Equity (ROE), which is estimated by the ratio of income before extraordinary items to book value of equity. To measure a firm's stability, we use the standard deviation of ROE during the most recent five years (STDROE). To measure labor intensity, we use revenue per employee (REVEMP). We measure the firm's financing needs (FINANCE) by the ratio of net stock and debt issuance during the 
most recent ten years to total assets. Net stock issuance represents the proceeds of stock issuance minus any cash used to repurchase shares. Net debt issuance represents the net proceeds from either long- or short-term debt. Finally, the variable REG is set to 1 if the firm belongs to a regulated industry, and 0 otherwise. Regulated firms are those that belong to the 2digit SIC industries 40, 46, 48, 49 and 60-64.

We test the hypotheses using the following Probit model for randomly selected years:

$$
\text { DISC }=\beta_{0}+\beta_{1} \text { LSALES }+\beta_{2} \text { CONC }+\beta_{3} \text { REG }+\beta_{4} \text { FINANCE }+\beta_{5} \text { ROE }+\beta_{6} \text { STDROE }+\beta_{7} \text { REVEMP }+\varepsilon
$$

The results of the Probit analysis are given in Tables 2A and 2B. Consistent with the hypotheses, the coefficients on size and regulation are positive and significant at the $1 \%$ level, and the coefficients on concentration are negative and significant at the $1 \%$ level. Although the existing literature has documented a positive relationship between the disclosure of earnings forecasts and profitability and stability, this relationship does not hold true for the retrospective labor costs disclosure. The coefficient on ROE and STDROE are not significant, although they are mostly in the expected direction. As expected, the variable REVEMP that proxies (inversely) for labor intensity is negatively and significantly correlated with the probability of labor-cost disclosure, DISC. In contrast to the stated hypothesis, the coefficient on the variable FINANCE is negative and significant, maybe because we use a 10 -year horizon for financing. Note that the results are consistent regardless of how we define DISC, with three levels of disclosure (Table $2 \mathrm{~A}$ ), or with only two levels (Table $2 \mathrm{~B}$ ). As a matter of fact, because the results in table $2 \mathrm{~B}$ are slightly stronger than those in $2 \mathrm{~A}$, it may suggest that there is a strong similarity between the firms that disclosed labor expense in some years and those that disclosed it consistently. 
Overall, we find that firms that voluntarily disclosed labor costs tend to be larger, regulated, more labor intensive, operate in more competitive industries, and have lower financing needs than firms that do not identify their labor costs separately. The association between labor cost disclosure and profitability and stability are found to be insignificant. These results are similar to the results found in other studies of corporate disclosure levels (e.g., Lang and Lundholm (1993)) in many respects, and yet there are significant differences. For instance, while our results regarding the impact of size, concentration, and regulation are in line with prior disclosure results, we find a significantly negative relationship between financing needs and labor cost disclosure. Similarly, we do not find profitability and stability to have a significant impact on labor cost disclosures. The fact that most of these earlier studies on voluntary disclosures have looked at the disclosure of prospective information such as earnings or sales forecasts, whereas we are looking at the disclosure level in annual reports may explain the difference in our results.

The results of this section indicate that the sample of firms we use in the study for human capital valuation represents a sample with unique characteristics, and generalizing from this sample to the larger population may well be problematic. However, we think that the results on human capital valuation will offer interesting insights on these firms.

\section{Valuing human capital}

In this section, we use the residual income model to estimate the valuation of labor expenditure by the capital markets and to determine the economic amortization rate for the asset human capital. 
In attempting to put a value to human capital for the purpose of recording them as assets in financial reports, earlier studies focused on the value of individual employees to the firm. For instance, Lev and Schwartz (1971) argued that an employee's expected economic value to the firm corresponds to the future earnings of the employee for the remaining active service life. Therefore, the value of the total human resources of the firm is determined by aggregating the present value of services of all employees. Flamholtz (1971) improved on this model by allowing the possibility of employees' career movements within the firm or the possibility of employees leaving the firm before retirement or death. However, determining the probabilities of career movement and early exit for each individual employee is usually a highly subjective exercise, thereby limiting the practicality of this model for valuing human assets. ${ }^{7}$ Recognizing the difficulty in predicting the promotion or exit of individual employees, Jaggi and Lau (1974) developed a stochastic model that used the group basis ${ }^{8}$ for the valuation of human capital arguing that, as in actuarial sciences, predicting patterns in group behavior is easier than predicting individual behavior.

As evident from these examples, in order to put a value to a firm's human assets these earlier models started at the individual employee level and then aggregated these values for all employees within the firm. In contrast, we start at the firm level and estimate the value of all human assets as a proportion of the total market value of the firm. By evaluating the value of human capital as a portion of the total value of the firm, our method implicitly takes into account the complementarities and synergies among all employees and between employees and all other factors of production within the firm.

\footnotetext{
${ }^{7}$ See Flamholtz (1987) for an application of this model to the valuation of human assets in a securities brokerage firm.

${ }^{8}$ Group refers not to a department or division but to a homogenous group of employees.
} 
In an analysis that also uses market data, but not the residual income valuation model used by our study, Hirschey and Weygandt (1985) analyzed the valuation of and the amortization rate for advertising and R\&D expenditures. Their approach consists of determining if these expenditures have a positive effect on a firm's Tobin Q (ratio of market value and replacement cost of assets). An affirmative answer, which they find for both advertising and R\&D expenditures, suggests that the market treats these expenditures as intangible capital investment. Further, they also provide a basis for determining a relevant range for the economic amortization rate for these variables. To do that, they cross-sectionally regress a firm's Tobin's q ratio on its advertising and $R \& D$ intensity. They then use the valuation coefficient from this regression to estimate the amortization rate for the two intangible variables. Our study is different, among other things, because it uses time-series data to estimate both of these parameters.

We begin by modifying the residual income model of valuation to explicitly incorporate investments in and depreciation of the human capital asset. To begin, suppose that a firm's market value is given by the sum of its future expected dividends. Under assumptions of clean surplus accounting, Ohlson (1995) shows that its market value can also be computed as the sum of its reported book value and the infinite sum of discounted residual income such that:

$$
\mathrm{MV}_{\mathrm{t}}=\mathrm{BV}_{\mathrm{t}}+\sum_{i=1}^{\infty} E\left[\frac{\mathrm{E}_{t+i}^{R}-\mathrm{r}_{\mathrm{f}} \mathrm{BV}_{t+i-1}}{\left(1+\mathrm{r}_{\mathrm{f}}\right)^{i}}\right]
$$

where $\mathrm{BV}_{\mathrm{t}}=$ book value (as reported) at time $\mathrm{t}$

$\mathrm{E}[]=$. expectations based on information at time $\mathrm{t}$

$\mathrm{E}_{\mathrm{t}}^{\mathrm{R}}=$ reported earnings for period $\mathrm{t}$

$\mathrm{r}_{\mathrm{f}}=$ cost of equity capital ( $=$ risk free interest rate given risk neutrality) 
Equation (2) obtains for every accounting system that satisfies the clean surplus relationship, because it allows us to substitute the change in book values and earnings for dividends in the valuation equation. The accounting system can be based on the current accounting practice of full expensing of labor-related costs, as long as it satisfies the clean surplus equation. Alternatively, an accounting system that capitalizes a portion of the labor-related costs can also provide parameters (earnings and changes in book values) for the valuation equation, as long as it satisfies the clean surplus equation. Thus, an accounting system that capitalizes some labor costs cannot be considered preferable to the current system based solely on its use in valuation. However, the two systems may have different characteristics for valuation if one makes further assumptions about the earnings generating process to obtain a simpler valuation equation.

In particular, Ohlson (1995) demonstrates that under additional assumptions of risk neutrality and a Markovian structure on the time series of abnormal earnings, the market value (MV) is a function of current book value (BV) and current abnormal earnings. Abnormal earnings are current earnings minus the risk free rate times the beginning of period book value. That is,

$$
M V_{t}=\alpha_{0}+\alpha_{1} B V_{t}+\alpha_{2}\left(E_{t}^{R}-r_{f} B V_{t-1}\right)+\gamma v_{t}
$$

where the variable $v_{t}$ captures information other than that pertaining to abnormal earnings, and $\alpha$ and $\gamma$ are functions of the risk free rate and the time series properties of abnormal earnings and other information.

Suppose a fraction $\beta$ (where $0<\beta<1$ ) of the labor expenses $\left(\mathrm{w}_{\mathrm{t}}\right)$ in each period represent additions to the human capital in the firm and that labor expenses grow at the rate of g percent 
every year, such that $\mathrm{w}_{\mathrm{t}}=(1+\mathrm{g}) \mathrm{w}_{\mathrm{t}-1}$. Further, if the rate of depreciation for this asset is $\delta$ (where $0<\delta<1)$ then the value of the human capital asset at the end of period $t\left(\mathrm{~L}_{\mathrm{t}}\right)$ is given by

$$
\mathrm{L}_{\mathrm{t}}=\beta \mathrm{w}_{\mathrm{t}}+(1-\delta) \mathrm{L}_{\mathrm{t}-1}
$$

Plugging in the value of $\mathrm{L}_{\mathrm{t}-1}$ recursively, we can write $\mathrm{L}_{\mathrm{t}}$ as:

$$
\begin{aligned}
\mathrm{L}_{\mathrm{t}} & =\beta \mathrm{w}_{\mathrm{t}}\left[1+\left(\frac{1-\delta}{1+\mathrm{g}}\right)+\left(\frac{1-\delta}{1+\mathrm{g}}\right)^{2}+\left(\frac{1-\delta}{1+\mathrm{g}}\right)^{3}+\ldots \ldots+\left(\frac{1-\delta}{1+\mathrm{g}}\right)^{\mathrm{t}}\right] \\
& =\beta \mathrm{w}_{\mathrm{t}}\left(\frac{1+\mathrm{g}}{\delta+\mathrm{g}}\right) \\
& \equiv \beta \phi \mathrm{w}_{\mathrm{t}}
\end{aligned}
$$

where the second equality is the sum of the series as $t$ approaches infinity and $\phi$ is defined as $(1+g) /(\delta+g)$. Similarly, for large $t$,

$$
\mathrm{L}_{\mathrm{t}-1}=\beta \phi \mathrm{w}_{\mathrm{t}-1}
$$

The extant financial reporting practice is to expense all labor-related costs in period $\mathrm{t}$ (under the assumption that all expenditure for labor is for current period's consumption). Thus, reported earnings $\left(\mathrm{E}^{\mathrm{R}}{ }_{\mathrm{t}}\right)$ are understated if some portion of this expenditure represents an investment in human capital, the benefits from which will accrue in future periods. Also, to the extent that this asset was depleted during the period, the result of such depletion should be charged against current periods' earnings as a depreciation expense. Therefore, the accounting system that capitalizes the investment in human capital will report earnings $\left(\mathrm{E}_{\mathrm{t}}\right)$, which, after making adjustments for additions to and depreciation of the human capital asset, are given by

$$
E_{t}=E_{t}^{R}+\beta w_{t}-\delta L_{t-1}
$$

Similarly, this accounting system will show book value of equity that is equal to the fullexpensing book value plus the human capital asset $\mathrm{L}_{\mathrm{t}}$. Plugging these adjusted values (under capitalization of some labor costs) of earnings and book values in equation (3) we get: 


$$
\mathrm{MV}_{\mathrm{t}}=\alpha_{0}+\alpha_{1}\left(\mathrm{BV}_{\mathrm{t}}+\mathrm{L}_{\mathrm{t}}\right)+\alpha_{2}\left(\mathrm{E}_{\mathrm{t}}^{\mathrm{R}}+\beta \mathrm{w}_{\mathrm{t}}-\delta \mathrm{L}_{\mathrm{t}-1}-\mathrm{r}_{\mathrm{f}}\left(\mathrm{BV}_{\mathrm{t}-1}+\mathrm{L}_{\mathrm{t}-1}\right)\right)+\gamma v_{\mathrm{t}}
$$

Note that equation (8) and equation (3) represent valuation equations which are based on two different accounting systems - one that has full expensing of labor costs, and another that capitalizes some of these costs. Notice that both of these valuation equations are correct if the accounting systems follow the clean surplus relationship, and if the resulting abnormal earnings follow the assumed Markovian process. In particular, the Markovian process assumes that the expected abnormal earnings in the current period are equal to abnormal earnings in the prior period times a persistence coefficient, which is less than one. It is reasonable to assume that both accounting systems comply with the clean surplus relationship. However, the abnormal earnings generated by the accounting system that capitalizes some labor costs are more likely to conform to the Markovian assumptions of abnormal earnings than those generated by the full expensing system. The reason is that under full expensing, the book value is consistently understated, and will become even more understated as the investment in human capital increases. Thus, abnormal earnings are actually expected to increase from one period to the next, instead of declining as assumed by the Markovian process. Thus, at least until that time in which the human capital asset stops growing, the accounting system that is based on capitalization of some labor costs is likely to yield abnormal earnings that better fit the underlying assumptions for valuation.

We describe below the application of the valuation equation that is based on a partial capitalization of labor expenses for a subset of firms that experienced a positive growth in labor expenses. Such firms are likely to be at the stage where the investment in human capital actually increases, and for which a valuation equation that is based on reported earnings and book values may be inferior to one which capitalizes some labor-related costs. 
If the dynamics of the human capital asset are as described in equations (4) and (5), substituting in the values of $\mathrm{L}_{\mathrm{t}}$ and $\mathrm{L}_{\mathrm{t}-1}$ and some manipulation, we can write equation (8) as

$$
\begin{aligned}
\mathrm{MV}_{\mathrm{t}} & =\alpha_{0}+\gamma v_{\mathrm{t}}+\alpha_{1} \mathrm{BV}_{\mathrm{t}}+\alpha_{2}\left(\mathrm{E}_{\mathrm{t}}^{\mathrm{R}}-\mathrm{r}_{\mathrm{f}} \mathrm{BV} \mathrm{V}_{\mathrm{t}-1}\right)+\left(\alpha_{1} \beta \phi+\alpha_{2} \beta\right) \mathrm{w}_{\mathrm{t}}-\left(\alpha_{2} \delta \beta \phi+\mathrm{r}_{\mathrm{f}} \alpha_{2} \beta \phi\right) \mathrm{w}_{\mathrm{t}-1} \\
& \equiv \mathrm{A}_{0}^{\prime}+\mathrm{A}_{1} \mathrm{BV}_{\mathrm{t}}+\mathrm{A}_{2}\left(\mathrm{E}_{\mathrm{t}}^{\mathrm{R}}-\mathrm{r}_{\mathrm{f}} \mathrm{BV}_{\mathrm{t}-1}\right)+\mathrm{A}_{3} \mathrm{~W}_{\mathrm{t}}+\mathrm{A}_{4} \mathrm{~W}_{\mathrm{t}-1}
\end{aligned}
$$

where:

$$
\begin{aligned}
& \mathrm{A}_{0}^{\prime} \equiv \alpha_{0}+\gamma v_{\mathrm{t}} \\
& \mathrm{A}_{1} \equiv \alpha_{1} \\
& \mathrm{~A}_{2} \equiv \alpha_{2} \\
& \mathrm{~A}_{3} \equiv\left(\alpha_{1} \beta \phi+\alpha_{2} \beta\right) \\
& \mathrm{A}_{4} \equiv-\alpha_{2} \beta \phi\left[\delta+\mathrm{r}_{\mathrm{f}}\right]
\end{aligned}
$$

Dividing equation (9) throughout by $\mathrm{BV}_{\mathrm{t}-1}$ and rearranging yields:

$$
\frac{\mathrm{MV}_{\mathrm{t}}}{\mathrm{BV}_{\mathrm{t}-1}}=\mathrm{A}_{0}+\mathrm{A}_{1} \frac{\mathrm{BV}_{\mathrm{t}}}{\mathrm{BV}_{\mathrm{t}-1}}+\mathrm{A}_{2} \frac{\mathrm{E}_{\mathrm{t}}^{\mathrm{R}}}{\mathrm{BV}_{\mathrm{t}-1}}+\mathrm{A}_{3} \frac{\mathrm{w}_{\mathrm{t}}}{\mathrm{BV}_{\mathrm{t}-1}}+\mathrm{A}_{4} \frac{\mathrm{w}_{\mathrm{t}-1}}{\mathrm{BV}_{\mathrm{t}-1}}
$$

Although Equation (10) is linear in the independent variables, its coefficients are non-linearly related, as can be easily ascertained from the expressions for $\mathrm{A}_{1}$ through $\mathrm{A}_{4}$. Estimation of this equation using OLS without restrictions on its coefficients is incorrect, and one has to resort to estimation methods that specifically incorporate the postulated relationships among the coefficients. In the following section, we describe the empirical estimation of the above equation. Using our estimates of the growth rate $g$ and the risk free rate $r_{f}$, we derive the investment and depreciation rates $(\beta$ and $\delta$ ) based on equation (10).

\section{Model and Parameter Estimation:}


Since the compensation structure of different firms varies widely and this Compustat item represents a fairly broad category of expenses, cross-sectional comparisons on the basis of this data item may not be particularly reliable. For instance, it is not clear whether items such as training costs and other long-term investments in human assets are also aggregated in this number for all firms. Our results therefore depend on time series rather than cross-sectional analysis.

To estimate the model, we use all firms that reported labor expense for at least 12 years during the period 1978-1997. We eliminated observations where the absolute value of the ratio of market to beginning book value of equity was greater than 100, and those observations where the absolute value of the change in the book value of equity over a year was greater than 10 times. We also eliminated any firm that did not have at least ten time-series observations for the final estimation, after elimination of outliers. We restricted ourselves to firms that had a positive growth rate in labor expenses over the available time-series data, where the growth rate represents the annual growth rate over the entire time series for the particular firm. The risk-free rate was assumed equal to $6.8 \%$, the average 90 -day yield on treasury bills for the study period. ${ }^{9}$

To estimate the parameters, we used a non-linear estimation technique (the SAS procedure MODEL) to estimate all the parameters in Equation (10). We placed a restriction on the parameters $\beta$ and $\delta$ to fall between zero and 0.5 , and placed penalties on being close to those boundaries. No attempt was made to restrict the intercept, the earnings coefficient, or the book value coefficient. ${ }^{10}$

Summary statistics about the estimates, as well as the ratio of the human capital asset (estimated according to Equation 5 above) to market values and the ratio of the human capital

\footnotetext{
${ }^{9}$ Prior studies, including Myers (1999) typically show that adjusting for risk does not improve the estimates. This is particularly true for time-series studies where changes in risk are probably negligible for most firms.
} 
asset to the difference between the market and book value of equity, are reported in Table 3 . The estimated earnings coefficient has a mean of 4.4 and a median of 4.9 , which are in line with prior studies (Ballester at al, 1998). Over $75 \%$ of the estimated earnings valuation coefficients are positive, as predicted by theory. The estimated $\beta$, which measures the proportion of labor expenditure that represents an investment in human capital assets, has a mean of $16 \%$, and a median of $10 \%$. Thus, the average (median) firm in our sample invests about $16 \%(10 \%)$ of total labor-related expenditures on building its human capital. This is an impressive proportion, but is probably not representative of other firms, since sample firms voluntarily disclosed labor data for a long period, presumably because it represented a significant cost for such firms.

The estimated $\delta$, which is the rate of depreciation of human capital assets, has a mean of $34 \%$ and a median of $40 \%$. This indicates that a typical firm in our sample loses about one third of its human capital assets every year due to such factors as turnover of employees and advancing technologies. As a comparison, Hirschey and Weygandt (1985) find that the economic amortization rate for R\&D expenditures falls in the 10 to $20 \%$ range (depending on the growth rate of these expenditures), whereas for advertising expenditures it falls in the 10 to $20 \%$ range in the non-durable goods sector and in the $30-60 \%$ range in the durable goods sector. As a caveat, it should be mentioned that their analysis is based on Fortune 500 companies for the year 1977 and uses a different valuation model. They also use cross-sectional analysis, whereas we use time series analysis for individual firms.

Using these estimates of $\beta$ and $\delta$, we used equation (5) to determine the value of the human capital asset $\mathrm{L}_{t}$ and divided it by the market value of the firm. This ratio expresses the

\footnotetext{
${ }^{10}$ We have used several other approaches to estimation of Equation (10), including restricting the coefficient on book value of equity to be one, adding the inverse of $\mathrm{BV}_{\mathrm{t}-1}$, and the elimination of an intercept. The results were not materially different from those reported in the text.
} 
value of the human capital assets as a proportion of the market value of the firm. The mean (median) value of this ratio was about 5\% (2\%). Further, the value of the human capital asset represents an average of about $16 \%$ of the difference between market and book value, and a median of about $3 \%$.

In order to test whether the estimated parameters and the resulting human capital asset make economic sense, we further test the association of the ratio of the human capital asset to market value of equity with the following firm characteristics:

1. Average salary - Firms which employ quality and skilled labor force are likely to invest more in training and developing their human capital assets and therefore, should have relatively higher ratios of human capital assets to market value. A skilled labor force commands a higher salary, so we expect a positive relationship between average salary and the human capital asset. Average salary is estimated by the ratio of 1997 labor expense to the number of employees.

2. Labor intensity - Labor intensive firms are more likely to invest in retention and training of this important input factor. Thus, we expect a positive relationship between the ratio of labor expense to sales and the human capital asset.

3. Operating uncertainty - When the environment is unstable, firms have to make larger investments in human capital in order to prepare employees for the rapid changes in the environment. Thus, we expect a positive relationship between the standard deviation of the return on equity (measured over the most recent five years), and the ratio of human capital asset to market value.

4. Profitability - Profitable firms do not need to make further investments in human capital. We expect such firms to have a negative relationship with investments in human capital. 
Profitability is measured as the return on assets (income before extraordinary items divided by total assets).

5. Growth - A growing firm needs all its available resources to sustain its growth, and is less likely to make investments to develop its human capital. Therefore, a negative relationship between growth and the investment in human capital is expected. Growth is estimated as the three-year historical growth of revenues.

6. Size - Larger firms do not expect employees to carry out more than one task, and invest less in their human capital. We expect a negative relationship between the investment in human capital and size. Size is estimated as the log of total assets.

7. Competition - Firms in less competitive (more concentrated) industries may invest more in developing their human assets because they enjoy a relatively protected environment (due perhaps to regulatory conditions and/or natural or technical barriers to entry). We measure competition by the four-firm concentration ratio. We expect a positive relationship between the concentration ratio and the ratio of human capital asset to market value of equity.

Table 4 provides information about the means and correlation coefficients for these variables. The average annual growth of sales is $10.8 \%$, consistent with the growing US economy during the years $1995-1997$. The average annual salary per employee is $\$ 55,898$, slightly above the average salary in the US, but it may include fringe benefits and employer taxes as well. The labor/sales ratio is quite high at $26.6 \%$, indicating the significance of labor expenses for the sample firms.

The table also reports correlation coefficients among the variables. We find a strong and positive correlation between the ratio of the human capital asset to market value of equity and 
the standard deviation of profits, the average salary, and the labor to sales ratio. We also find a negative and statistically significant correlation between the human capital asset and the firm's size. Most other correlation coefficients are not significantly different from zero, and even those that are do not exhibit very high correlations that may indicate multi-collinearity.

Table 5 presents regression results, where the dependent variable is the ratio of the human capital asset to market value of equity, and the independent variables are those mentioned above. As can be seen from the table, growth is negatively associated with investment in human capital, although this association is generally not statistically significant. The environmental uncertainty of a firm (as captured by the standard deviation of ROE) is positively and significantly associated with the human capital asset, presumably because firms need to spend more on human capital in fluid environments. We also find that the average salary is positively and significantly related to the ratio of human capital to market value, as expected by intuition. Similarly, the ratio of labor expense to sales is positively and significantly associated with the ratio of human capital to market value, presumably because labor intensive firms invest more in their human capital. Finally, there is a negative and statistically significant association between the size of a firm and its human capital investment, possibly because larger firms tend to hire trained employees for specific jobs.

In summary, the estimates obtained for the proportion of labor expenses that represent investment in human capital, $\beta$, and the resulting estimates of the human capital asset, seem to have reasonable values, and to be systematically related to certain variables that are expected to be associated with these estimates in a predictable manner. 


\section{Summary and Conclusions}

This study investigates the reasons for voluntary disclosure of labor costs. It finds that larger and regulated firms are more likely to voluntarily disclose labor costs, presumably because of greater political costs for such firms. Also, firms that are more labor intensive are more likely to report labor costs separately, presumably because these costs are material to the firms. It also finds that firms in less competitive industries are less likely to disclose labor costs to retain their competitive advantage.

The study also estimates the proportion of labor costs that represent an investment in human capital, and finds it to be about $16 \%$ for the average firm in the sample of firms that voluntarily disclose labor costs. The study also shows that the human capital asset in this sample is amortized about $34 \%$ per year. The human capital asset of a firm is shown to be systematically related to operating uncertainty, average pay, the ratio of labor expenses to sales, and inversely related to size. We also find that human capital assets, on average, represent about $5 \%$ of the market value of the firm and account for about $16 \%$ of the difference between market and book value.

The theoretical derivation and the methodology of this study can be used in other areas of intangible assets that are currently expensed for accounting purposes. Such items may include advertising expenses and $\mathrm{R} \& \mathrm{D}$ expenditures. 


\section{References}

Ballester, M., J. Livnat and C. Seethamraju, "Individual-Firm Style Loadings, Unrecorded Economic Assets and Systematic Risk", Journal of Accounting, Auditing and Finance, Summer 1998, 13:3, pp. 275-296.

Barth, M.E., M.B. Clement, G. Foster, and R. Kasznik (1998). "Brand Values and Capital Market Valuation," Review of Accounting Studies 3: 41-68.

Bernard, V. (1995). "The Feltham-Ohlson Framework: Implications for Empricists." Contemporary Accounting Research 11: 733-747.

Botosan, C. (1997). "Disclosure Level and the Cost of Equity Capital." The Accounting Review: (July): 323-349.

Clarkson, P. M., A. Dontoh, G. D. Richardson and S. Sefcik (1992). "The Voluntary Inclusion of Earnings Forecasts in IPO Prospectuses. ." Contemporary Accounting Research 9: 601626.

Clarkson, P. M., J. L. Kao and G. D. Richardson (1994). " The Voluntary Inclusion of Forecasts in the MD\&A section of Annual Reports." Contemporary Accounting Research 11: 489496.

Clarkson, P.M., Yue Li and G. D. Richardson (1998). "The Market Valuation of Environmental Capital Expenditures by Pulp and Paper Companies." Working Paper., University of Waterloo.

Darrough, M. and N. Stoughton. (1990). "Financial disclosure policy in an entry game." Journal of Accounting and Economics 12 (January): 219-243.

Darrough, M. (1991). "Disclosure policy and competition: Cournot vs. Bertrand." The Accounting Review: : 534-561.

Dontoh, A. (1990). "Voluntary disclosure." Journal of Accounting, Auditing, and Finance 4: 488-511.

Feltham, G. A. and J. A. Ohlson (1996). "Uncertainty Resolution and The Theory of Depreciation Measurement." Journal of Accounting Research 34: 209-224.

Feltham, G. A. and J. A. Ohlson (1995). "Valuation and Clean Surplus Accounting for Operating and Financial Acitvities." Contemporary Accounting Research 11: 689-731.

Flamholtz, E. (1971) "A Model for Human Resource Valuation: A Stochastic Process with Service Rewards.” The Accounting Review 46 2: 253-67. 
Flamholtz, E.(1987) "Valuation of Human Assets in a Securities Brokerage Birm: an Empirical Study." Accounting Organizations and Society 12:309-318.

Frankel, McNichols and Wilson (1995). "Discretionary Disclosures and External Financing." The Accounting Review: 135-150.

Hirschey, M. and J. J. Weygandt. (1985). "Amortization Policy for Advertising and Research and Development Expenditures.” Journal of Accounting Research 23 1: 326-335.

Jaggi, B. and Hon-Shiang Lau (1974). "Toward a Model for Human Resource Valuation." The Accounting Review, 49 2: 321-29.

Lang, M. and R. Lundholm (1993). "Cross Sectional Determinants of analyst ratings of Corporate disclosures." Journal of Accounting Research 31:246-271.

Lev B. and A. Schwartz (1971). "On the Use of the Economic Concept of Human Capital in Financial Statements." The Accounting Review (January): 103-111.

Myers, J. N. (1999) "Implementing Residual Income Valuation with Linear Information Dynamics." The Accounting Review (January): 1-28.

Ohlson, J. A. (1995). "Earnings, Book Values, and Dividends in Security Valuations." Contemporary Accounting Research 11: 661-687.

Ohlson, J. A. (1998). "Discussion of Brand Values and Capital Market Valuation," Review of Accounting Studies 3: 69-71. 


\section{Figure 1}

\section{Labor Expenses and Ratios}

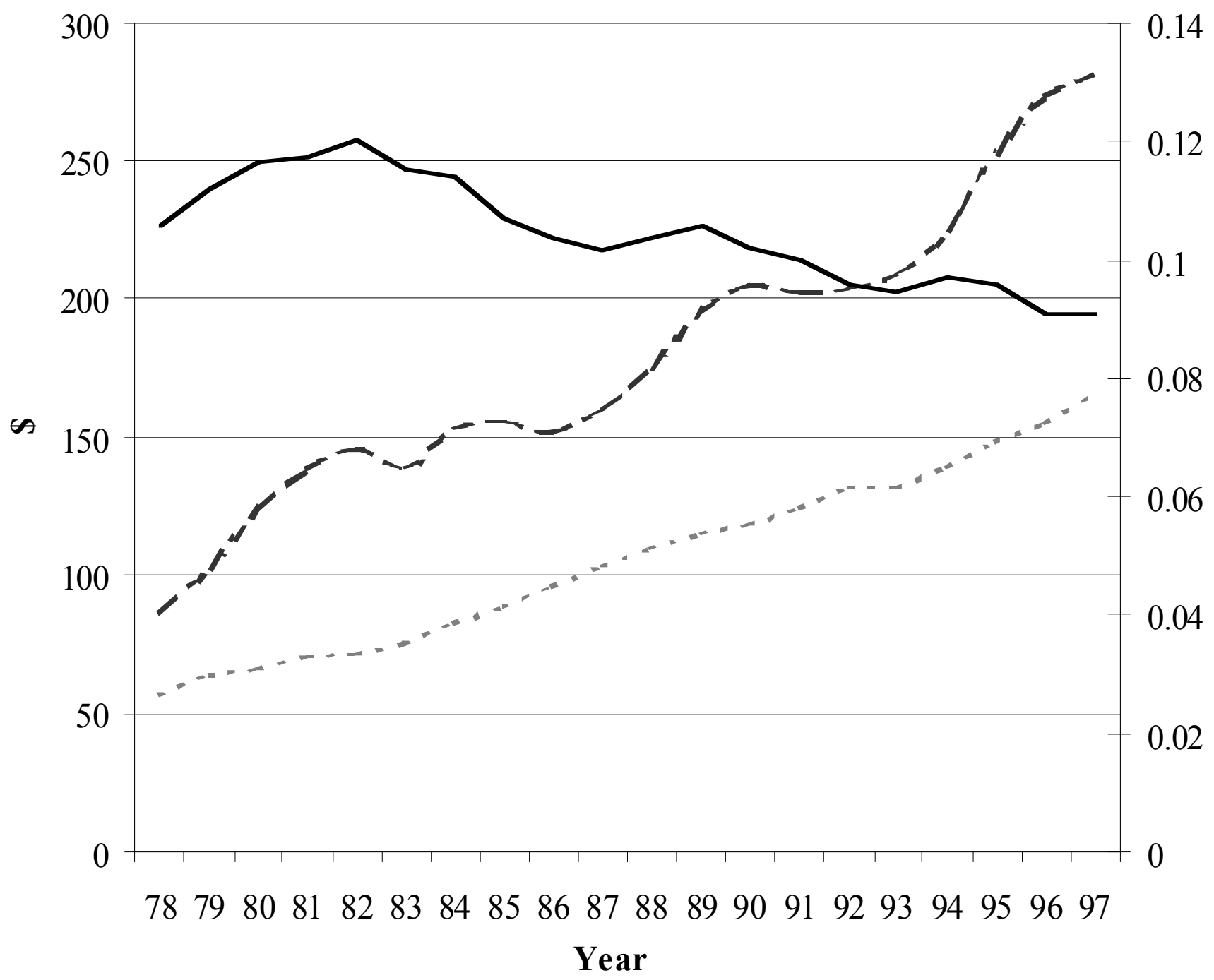

" - - " Average Labor (in \$10 Millions)

— - Av erage Sales/employee (in \$000)

Average labor/sales 
Table 1A

Summary Statistics for Disclosing and Non-Disclosing Firms

\begin{tabular}{|c|c|c|c|c|c|c|c|c|c|}
\hline Variables & $\mathbf{N}$ & Mean & Min. & 25th & Median & 75th & Max. & $\begin{array}{l}\text { t-statistic } \\
\text { Significance* }\end{array}$ & $\begin{array}{l}\text { Wilcoxon } \\
\text { Significance* }\end{array}$ \\
\hline \multicolumn{10}{|l|}{ Assets (in millions) } \\
\hline - Disclosing & 157 & 29,703 & 5 & 1,596 & 9,123 & 22,668 & 336,099 & & \\
\hline - Non Disclosing & 1230 & 1,758 & 0 & 24 & 92 & 447 & 227,419 & 0.001 & 0.001 \\
\hline Sales (in millions) & & & & & & & & & \\
\hline - Disclosing & 157 & 7,879 & 2 & 765 & 2,060 & 7,280 & 160,121 & & \\
\hline - Non Disclosing & 1230 & 758 & 1 & 16 & 69 & 349 & 35,284 & 0.001 & 0.001 \\
\hline No. of Employees & & & & & & & & & \\
\hline - Disclosing & 157 & 30.980 & 0.002 & 4.065 & 10.100 & 33.414 & 647.000 & & \\
\hline - Non Disclosing & 1230 & 3.648 & 0.001 & 0.099 & 0.381 & 1.900 & 192.000 & 0.001 & 0.001 \\
\hline \multicolumn{10}{|l|}{ Concentration } \\
\hline - Disclosing & 157 & 0.530 & 0.219 & 0.369 & 0.465 & 0.638 & 0.997 & & \\
\hline - Non Disclosing & 1225 & 0.593 & 0.138 & 0.470 & 0.595 & 0.758 & 0.997 & 0.001 & 0.001 \\
\hline \multicolumn{10}{|l|}{$\begin{array}{l}\text { Rev/Emp (in } \\
\text { thousands) }\end{array}$} \\
\hline $\begin{array}{l}\text { - Non Disclosing } \\
\text { ROE }\end{array}$ & 1230 & 294.4 & 9.4 & 106.2 & 173.4 & 306.2 & 7015.4 & 0.366 & 0.004 \\
\hline - Disclosing & 157 & 0.154 & -0.330 & 0.119 & 0.156 & 0.191 & 0.421 & & \\
\hline $\begin{array}{l}\text { - Non Disclosing } \\
\text { Std Dev ROE }\end{array}$ & 1230 & -0.005 & -5.000 & -0.054 & 0.086 & 0.162 & 5.000 & 0.012 & 0.001 \\
\hline - Disclosing & 157 & 0.064 & 0.003 & 0.015 & 0.032 & 0.067 & 1.555 & & \\
\hline - Non Disclosing & 1217 & 0.788 & 0.001 & 0.047 & 0.119 & 0.410 & 44.471 & 0.002 & 0.001 \\
\hline \multicolumn{10}{|l|}{ Finance } \\
\hline - Disclosing & 157 & 0.012 & -1.680 & -0.005 & 0.000 & 0.051 & 0.573 & & \\
\hline - Non Disclosing & 1230 & 0.620 & -3.320 & 0.030 & 0.274 & 0.622 & 148.888 & 0.081 & 0.001 \\
\hline \multicolumn{10}{|l|}{ Regulated } \\
\hline - Disclosing & 157 & 0.529 & 0 & 0 & 1 & 1 & 1 & & \\
\hline - Non Disclosing & 1230 & 0.176 & 0 & 0 & 0 & 0 & 1 & 0.001 & 0.001 \\
\hline \multicolumn{10}{|l|}{ Sales Growth } \\
\hline - Disclosing & 157 & 8.0 & -10.5 & 4.2 & 7.5 & 11.4 & 33.2 & & \\
\hline - Non Disclosing & 804 & 16.7 & -45.0 & 3.2 & 10.0 & 22.9 & 344.6 & 0.001 & 0.001 \\
\hline
\end{tabular}

Notes to Table 1A:

1. Disclosing firms are those that reported labor-related expenses for every year during the period 1978-1997. Nondisclosing firms did not disclose labor-related expenses for any year during that time period. Data in the table are for 1996.

2. The number of employees is reported in thousands.

3. Concentration is measured by the ratio of revenues of the largest four firms to total revenues of all firms within the same four-digit SIC industry.

4. Rev/Emp represents the ratio of total firm's revenues to the number of employees.

5. ROE is the ratio of income before extraordinary items to book value of equity.

6. Std Dev ROE represents the standard deviation of ROE over the five-year period ending in the year of analysis.

7. Finance represents the ratio of net financing in the most recent 10 years to total assets. Net financing represents proceeds from the net issuance of equity, long- and short-term debt.

8. Regulated firms are those that belong to the 2-digit SIC industries 40, 46, 48, 49 and 60-64.

9. Sales growth represents the annual percentage growth in revenues over the most recent five years.

* Two-tail tests of significance 
Table 1B

\section{Correlation Matrix}

\begin{tabular}{|c|c|c|c|c|c|c|c|c|c|}
\hline Variables & Asset & $\begin{array}{l}\text { Log } \\
\text { Sales }\end{array}$ & $\begin{array}{c}\text { \#Emp } \\
\text { loyee } \\
\mathrm{s}\end{array}$ & $\begin{array}{c}\text { Concen } \\
\text { ration }\end{array}$ & $\begin{array}{c}\mathrm{REV} / \mathrm{E} \\
\mathrm{MP}\end{array}$ & ROE & $\begin{array}{l}\text { Std. } \\
\text { Dev } \\
\text { ROE }\end{array}$ & $\begin{array}{c}\text { Financ } \\
\text { ing }\end{array}$ & Regulated \\
\hline Assets & 1 & $\begin{array}{c}.37 \\
(.00)\end{array}$ & $\begin{array}{c}.42 \\
(.00)\end{array}$ & $\begin{array}{c}-.09 \\
(.00)\end{array}$ & $\begin{array}{c}.07 \\
(.00)\end{array}$ & $\begin{array}{c}.04 \\
(.00)\end{array}$ & $\begin{array}{l}-.01 \\
(.57)\end{array}$ & $\begin{array}{l}-.03 \\
(.01)\end{array}$ & $\begin{array}{l}.20 \\
(.00)\end{array}$ \\
\hline Log Sales & & 1 & $\begin{array}{c}.39 \\
(.00)\end{array}$ & $\begin{array}{c}-.21 \\
(.00)\end{array}$ & $\begin{array}{l}.10 \\
(.00)\end{array}$ & $\begin{array}{l}.14 \\
(.00)\end{array}$ & $\begin{array}{l}-.01 \\
(.23)\end{array}$ & $\begin{array}{l}-.15 \\
(.00)\end{array}$ & $\begin{array}{c}.30 \\
(.00)\end{array}$ \\
\hline \#Employees & & & 1 & $\begin{array}{l}.02 \\
(.05)\end{array}$ & $\begin{array}{c}-.03 \\
(.01)\end{array}$ & $\begin{array}{c}.03 \\
(.02)\end{array}$ & $\begin{array}{l}-.01 \\
(.60)\end{array}$ & $\begin{array}{l}-.03 \\
(.01)\end{array}$ & $\begin{array}{l}-.02 \\
(.09)\end{array}$ \\
\hline Concentration & & & & 1 & $\begin{array}{c}-.10 \\
(.00)\end{array}$ & $\begin{array}{l}-.02 \\
(.08)\end{array}$ & $\begin{array}{c}.01 \\
(.23)\end{array}$ & $\begin{array}{l}-.00 \\
(.81)\end{array}$ & $\begin{array}{l}-.44 \\
(.00)\end{array}$ \\
\hline REV/EMP & & & & & 1 & $\begin{array}{c}.03 \\
(.02)\end{array}$ & $\begin{array}{l}-.00 \\
(.82)\end{array}$ & $\begin{array}{l}-.03 \\
(.01)\end{array}$ & $\begin{array}{c}.07 \\
(.00)\end{array}$ \\
\hline ROE & & & & & & 1 & $\begin{array}{c}.01 \\
(.42)\end{array}$ & $\begin{array}{l}-.02 \\
(.05)\end{array}$ & $\begin{array}{c}.08 \\
(.00)\end{array}$ \\
\hline Std Dev ROE & & & & & & & 1 & $\begin{array}{l}.01 \\
(.43)\end{array}$ & $\begin{array}{l}.02 \\
(.15)\end{array}$ \\
\hline Financing & & & & & & & & 1 & $\begin{array}{l}-.06 \\
(.00)\end{array}$ \\
\hline
\end{tabular}

\section{Notes to Table 1B:}

1. Data in the table are for 1996. Table entries represent Pearson correlations with significance levels in parentheses.

2. For variable definitions see the notes to table $1 \mathrm{~A}$. 
Table 2A

Probit Analysis - Voluntary Disclosure of Labor Costs - Three Groups

Model: DISC $=\beta_{0}+\beta_{1}$ LSALES $+\beta_{2}$ CONC $+\beta_{3}$ REG $+\beta_{4}$ FINANCE $+\beta_{5}$ ROE $+\beta_{6}$ STDROE $+\beta_{7}$ REVEMP $+\varepsilon$

\begin{tabular}{|l|c|rrrrr|}
\hline & Expected & $\mathbf{1 9 8 6}$ & $\mathbf{1 9 9 2}$ & $\mathbf{1 9 9 6}$ & $\mathbf{1 9 9 7}$ & All \\
Variable & Sign & & & & & \\
& & & & & & \\
LSALES & + & $\mathbf{0 . 1 7 9}$ & $\mathbf{0 . 1 5 2}$ & $\mathbf{0 . 0 1 3}$ & $\mathbf{0 . 0 1 4}$ & $\mathbf{0 . 1 5 0}$ \\
& & $\mathbf{0 . 0 0 1}$ & $\mathbf{0 . 0 0 1}$ & $\mathbf{0 . 0 0 1}$ & $\mathbf{0 . 0 0 1}$ & $\mathbf{0 . 0 0 1}$ \\
CONC & - & $\mathbf{- 0 . 7 9 6}$ & $\mathbf{- 1 . 1 7 4}$ & $\mathbf{- 0 . 9 6 9}$ & $\mathbf{- 0 . 0 6 8}$ & $\mathbf{- 0 . 8 8 9}$ \\
& & $\mathbf{0 . 0 0 1}$ & $\mathbf{0 . 0 0 1}$ & $\mathbf{0 . 0 0 1}$ & $\mathbf{0 . 0 0 1}$ & $\mathbf{0 . 0 0 1}$ \\
REG & + & $\mathbf{0 . 3 6 9}$ & $\mathbf{0 . 4 3 8}$ & $\mathbf{0 . 6 3 7}$ & $\mathbf{0 . 6 8 2}$ & $\mathbf{0 . 5 4 2}$ \\
& & $\mathbf{0 . 0 0 1}$ & $\mathbf{0 . 0 0 1}$ & $\mathbf{0 . 0 0 1}$ & $\mathbf{0 . 0 0 1}$ & $\mathbf{0 . 0 0 1}$ \\
FINANCE & + & -0.014 & -0.059 & $\mathbf{- 0 . 0 8 5}$ & $\mathbf{- 0 . 1 2 5}$ & $\mathbf{- 0 . 0 8 0}$ \\
& & 0.863 & 0.095 & $\mathbf{0 . 0 0 4}$ & $\mathbf{0 . 0 0 5}$ & $\mathbf{0 . 0 0 1}$ \\
ROE & + & $\mathbf{0 . 1 4 4}$ & 0.064 & 0.020 & -0.027 & 0.034 \\
& & $\mathbf{0 . 0 3 7}$ & 0.233 & 0.705 & 0.527 & 0.184 \\
STDROE & - & $\mathbf{- 0 . 0 2 0}$ & -0.002 & 0.009 & 0.001 & 0.001 \\
& & $\mathbf{0 . 0 0 7}$ & 0.735 & 0.305 & 0.471 & 0.506 \\
REVEMP & - & -0.0003 & -0.0001 & $\mathbf{- 0 . 0 0 0 4}$ & $\mathbf{- 0 . 0 0 0 1}$ & $\mathbf{- 0 . 0 0 0 2}$ \\
& & 0.133 & 0.300 & $\mathbf{0 . 0 0 1}$ & $\mathbf{0 . 0 1 5}$ & $\mathbf{0 . 0 0 1}$ \\
& & & & & & \\
\hline N(DISC = -1) & & 1200 & 1123 & 1212 & 1052 & 4587 \\
N(DISC = 0) & & 368 & 456 & 562 & 523 & 1909 \\
N(DISC = 1) & & 151 & 151 & 151 & 151 & 604 \\
\hline \multirow{2}{*}{ Chi-Square } & & & & & & \\
& & 3543.3 & 3579.0 & $\mathbf{5 1 5 3 . 4}$ & $\mathbf{3 6 3 7 . 8}$ & $\mathbf{1 7 0 1 0 . 9}$ \\
& & 0.064 & 0.057 & $\mathbf{0 . 0 0 1}$ & $\mathbf{0 . 0 1 0}$ & $\mathbf{0 . 0 0 1}$ \\
\hline
\end{tabular}

Notes to table 2A:

1. Table results are for four randomly selected years. All represents the analysis of all observations with a year dummy.

2. DISC is the discrete dependent variable taking on values of 1 if the firm disclosed labor costs in all years 19781997, 0 if labor costs were disclosed in some but not all of the years, and -1 if labor costs were never disclosed during that period.

3. LSALES represents the log of sales.

4. Concentration is measured by the ratio of revenues of the largest four firms to total revenues of all firms within the same four-digit SIC industry.

5. REVEMP represents the ratio of total firm's revenues to the number of employees.

6. ROE is the ratio of income before extraordinary items to book value of equity.

7. STDROE represents the standard deviation of ROE over the five-year period ending in the year of analysis.

8. FINANCE represents the ratio of net financing in the most recent 10 years to total assets. Net financing represents proceeds from the net issuance of equity, long- and short-term debt.

9. REG Regulated firms are those that belong to the 2-digit SIC industries 40, 46, 48, 49 and 60-64. 
Table 2B

Probit Analysis - Voluntary Disclosure of Labor Costs - Two Groups

Model: DISC $=\beta_{0}+\beta_{1}$ LSALES $+\beta_{2}$ CONC $+\beta_{3}$ REG $+\beta_{4}$ FINANCE $+\beta_{5}$ ROE $+\beta_{6}$ STDROE $+\beta_{7}$ REVEMP $+\varepsilon$

\begin{tabular}{|c|c|c|c|c|c|c|}
\hline Variable & \begin{tabular}{|c|} 
Expected \\
Sign
\end{tabular} & 1986 & 1992 & 1996 & 1997 & All \\
\hline LSALES & + & $\begin{array}{r}0.210 \\
0.001\end{array}$ & $\begin{array}{r}0.193 \\
0.001\end{array}$ & $\begin{array}{r}0.177 \\
0.001\end{array}$ & $\begin{array}{r}0.186 \\
0.001\end{array}$ & $\begin{array}{r}0.193 \\
0.001\end{array}$ \\
\hline CONC & - & $\begin{array}{r}-0.740 \\
0.001\end{array}$ & $\begin{array}{r}-1.093 \\
0.001\end{array}$ & $\begin{array}{r}-0.861 \\
0.001\end{array}$ & $\begin{array}{r}-0.577 \\
0.004\end{array}$ & $\begin{array}{r}-0.787 \\
0.001\end{array}$ \\
\hline REG & + & $\begin{array}{r}\mathbf{0 . 3 7 7} \\
\mathbf{0 . 0 0 1}\end{array}$ & $\begin{array}{r}\mathbf{0 . 4 5 3} \\
0.001\end{array}$ & $\begin{array}{r}0.717 \\
0.001\end{array}$ & $\begin{array}{r}0.774 \\
0.001\end{array}$ & $\begin{array}{r}0.591 \\
0.001\end{array}$ \\
\hline FINANCE & + & $\begin{array}{r}-0.058 \\
0.534\end{array}$ & $\begin{array}{r}-0.063 \\
0.104\end{array}$ & $\begin{array}{r}-0.082 \\
0.010\end{array}$ & $\begin{array}{r}-0.122 \\
0.012\end{array}$ & $\begin{array}{r}-0.082 \\
0.001\end{array}$ \\
\hline ROE & + & $\begin{array}{r}0.145 \\
0.047\end{array}$ & $\begin{array}{r}0.066 \\
0.256\end{array}$ & $\begin{array}{r}0.016 \\
0.782\end{array}$ & $\begin{array}{r}-0.026 \\
0.577\end{array}$ & $\begin{array}{r}0.035 \\
0.238\end{array}$ \\
\hline STDROE & - & $\begin{array}{r}-0.204 \\
0.010\end{array}$ & $\begin{array}{r}-0.003 \\
0.664\end{array}$ & $\begin{array}{r}0.008 \\
0.368\end{array}$ & $\begin{array}{r}0.001 \\
0.548\end{array}$ & $\begin{array}{r}0.001 \\
0.488\end{array}$ \\
\hline REVEMP & - & $\begin{array}{r}-0.0004 \\
0.064\end{array}$ & $\begin{array}{r}-0.0001 \\
0.163\end{array}$ & $\begin{array}{r}-0.0005 \\
0.001\end{array}$ & $\begin{array}{r}-0.0002 \\
0.005\end{array}$ & $\begin{array}{r}-0.0003 \\
0.001\end{array}$ \\
\hline $\begin{array}{l}\mathrm{N}(\mathrm{DISC}=\mathbf{- 1}) \\
\mathrm{N}(\mathrm{DISC}=\mathbf{0 , 1})\end{array}$ & & $\begin{array}{r}1200 \\
519 \\
\end{array}$ & $\begin{array}{r}1123 \\
607 \\
\end{array}$ & $\begin{array}{r}1212 \\
713 \\
\end{array}$ & $\begin{array}{r}1052 \\
674 \\
\end{array}$ & $\begin{array}{l}4587 \\
2513 \\
\end{array}$ \\
\hline Chi-Square & & $\begin{array}{r}1828.7 \\
0.019\end{array}$ & $\begin{array}{r}1911.3 \\
0.001\end{array}$ & $\begin{array}{r}2938.9 \\
0.001\end{array}$ & $\begin{array}{r}1990.0 \\
0.001\end{array}$ & $\begin{array}{r}10529.2 \\
0.001\end{array}$ \\
\hline
\end{tabular}

Notes to Table 2B:

1. Table results are for four randomly selected years. All represents the analysis of all observations with a year dummy.

2. DISC is the discrete dependent variable taking on values of 1 if the firm disclosed labor costs in at least one year during 1978-1997, and -1 if labor costs were never disclosed during that period.

3. See notes to Table $2 \mathrm{~A}$ for variable definitions. 


\section{Table 3}

\section{Summary Statistics of Parameter Estimates}

$$
\begin{gathered}
\frac{\mathrm{MV}_{\mathrm{t}}}{\mathrm{BV}_{\mathrm{t}-1}}=\mathrm{A}_{0}+\mathrm{A}_{1} \frac{\mathrm{BV}_{\mathrm{t}}}{\mathrm{BV}_{\mathrm{t}-1}}+\mathrm{A}_{2} \frac{\mathrm{E}_{\mathrm{t}}^{\mathrm{R}}}{\mathrm{BV}_{\mathrm{t}-1}}+\mathrm{A}_{3} \frac{\mathrm{w}_{\mathrm{t}}}{\mathrm{BV}_{\mathrm{t}-1}}+\mathrm{A}_{4} \frac{\mathrm{w}_{\mathrm{t}-1}}{\mathrm{BV}_{\mathrm{t}-1}} \\
\mathrm{~A}_{1} \equiv \alpha_{1} ; \mathrm{A}_{2} \equiv \alpha_{2} ; \mathrm{A}_{3} \equiv\left(\alpha_{1} \beta \phi+\alpha_{2} \beta\right) ; \mathrm{A}_{4} \equiv-\alpha_{2} \beta \phi\left[\delta+\mathrm{r}_{\mathrm{f}}\right] ; \phi \equiv(1+\mathrm{g}) /(\delta+\mathrm{g}) \\
\mathrm{HU}=\mathrm{L}_{\mathrm{t}}=\beta \phi \mathrm{w}_{\mathrm{t}}
\end{gathered}
$$

\begin{tabular}{|l|rr|rrrrrrr|}
\hline & $\mathbf{N}$ & Mean & Minimum & $\mathbf{1 0 \%}$ & $\mathbf{2 5 \%}$ & $\mathbf{5 0 \%}$ & $\mathbf{7 5 \%}$ & $\mathbf{9 0 \%}$ & Maximum \\
\hline Alpha $\left(\alpha_{2}\right)$ & 269 & 4.412 & -11.371 & -1.526 & 2.003 & 4.891 & 5.191 & 10.000 & 35.957 \\
\hline Beta $(\beta$ & 269 & 0.158 & 0.000 & 0.002 & 0.058 & 0.100 & 0.226 & 0.416 & 0.499 \\
\hline Delta $(\delta$ & 269 & 0.342 & 0.000 & 0.085 & 0.275 & 0.400 & 0.442 & 0.498 & 0.499 \\
\hline $\begin{array}{l}\text { Intercept } \\
\left(\alpha_{\mathbf{0}}\right)\end{array}$ & 269 & 0.129 & -7.367 & -1.442 & -0.190 & 0.000 & 0.162 & 1.514 & 21.640 \\
\hline Book $\left(\alpha_{1}\right)$ & 269 & 0.750 & -17.433 & -1.283 & 0.718 & 0.950 & 1.116 & 2.060 \\
\hline HU/MV & 259 & 0.049 & 0.000 & 0.000 & 0.005 & 0.020 & 0.060 & 0.121 & 0.474 \\
\hline $\begin{array}{l}\text { HU/MV- } \\
\text { BV) }\end{array}$ & 249 & 0.159 & 0.000 & 0.000 & 0.007 & 0.031 & 0.110 & 0.284 \\
\hline
\end{tabular}

Notes:

1. Alpha is the earnings valuation coefficient in equation (10). It measures the effect of a dollar of earnings on market value of equity.

2. Beta measures the proportion of current labor expense that represents an addition to the human capital assets of the firm.

3. Delta is the rate of depreciation of the human capital assets of the firm.

4. Intercept is the intercept in equation (10).

5. Book is the coefficient on the book value of equity variable in equation (10). It is expected to be one.

6. HU/MV is the ratio of the estimated human capital asset to the market value of equity. Observations with ratios above $90 \%$ are deleted.

7. $\mathrm{HU} /(\mathrm{MV}-\mathrm{BV})$ is the ratio of the estimated human capital asset to the difference between the market and book value of equity. Observations where the book value exceeds market value are deleted. 
Table 4

Means and Correlations

\begin{tabular}{|c|c|c|c|c|c|c|c|c|c|}
\hline \multirow[b]{3}{*}{ Variable } & \multirow[b]{3}{*}{ Mean } & \multirow[b]{3}{*}{$\mathbf{N}$} & \multicolumn{5}{|c|}{ Correlations } & \multirow[b]{2}{*}{ Labor/ } & \multirow[b]{3}{*}{ Log(assets) } \\
\hline & & & & Sales & Std Dev & Average & & & \\
\hline & & & HU/MV & Growth & ROE & Salary & ROA & Sales & \\
\hline HU/MV & 0.049 & 259 & 1 & & & & & & \\
\hline Sales Growth & 10.769 & 199 & -0.089 & 1 & & & & & \\
\hline Std Dev ROE & 0.078 & 248 & 0.222 & -0.098 & 1 & & & & \\
\hline Average Salary & 55.898 & 214 & 0.166 & 0.174 & 0.011 & 1 & & & \\
\hline ROA & 0.039 & 248 & -0.078 & -0.071 & 0.004 & -0.089 & 1 & & \\
\hline Labor/Sales & 0.266 & 216 & 0.405 & 0.101 & 0.072 & 0.331 & -0.084 & 1 & \\
\hline Log(Assets) & 8.222 & 248 & -0.299 & 0.266 & -0.073 & 0.155 & -0.222 & -0.284 & 1 \\
\hline Concentration & 0.504 & 243 & 0.057 & 0.095 & -0.033 & 0.093 & 0.133 & 0.256 & -0.118 \\
\hline
\end{tabular}

Notes:

1. HU/MV is the ratio of the estimated human capital asset to the market value of equity.

2. Sales growth is estimated as the annualized (percentage) growth over the most recent three years.

3. Std Dev ROE represents the standard deviation of return (income) on (book) equity over the most recent five years.

4. Average salary (in thousands) is the total labor expense divided by number of employees.

5. ROA is the return (income before extraordinary items) on total assets.

6. Labor/Sales is the ratio of labor expense to total sales.

7. $\log$ (Assets) is a measure of size.

8. Concentration is the ratio of the four largest firms' sales to total industry sales.

9. Bold entries for correlations represent statistically significant correlations. 
Table 5

Regression Results

\begin{tabular}{|c|c|c|c|c|c|c|}
\hline Variable & $\begin{array}{c}\text { Expected } \\
\text { Sign }\end{array}$ & Model 1 & Model 2 & Model 3 & Model 4 & Model 5 \\
\hline Intercept & $?$ & $\begin{array}{r}0.043 \\
0.021\end{array}$ & $\begin{array}{r}0.079 \\
0.006\end{array}$ & $\begin{array}{r}-0.004 \\
0.784\end{array}$ & $\begin{array}{r}0.038 \\
0.079\end{array}$ & $\begin{array}{l}0.04 \\
0.029\end{array}$ \\
\hline Sales growth & - & $\begin{array}{r}-0.001 \\
0.151\end{array}$ & & \begin{tabular}{r|}
-0.001 \\
0.025
\end{tabular} & $\begin{array}{r}-0.001 \\
0.257\end{array}$ & $\begin{array}{r}-0.001 \\
0.158\end{array}$ \\
\hline Std Dev ROE & + & $\begin{array}{r}0.031 \\
0.019\end{array}$ & $\begin{array}{r}0.065 \\
0.001\end{array}$ & $\begin{array}{l}\mathbf{0 . 0 3} \\
\mathbf{0 . 0 2 7}\end{array}$ & $\begin{array}{r}\mathbf{0 . 0 3 3} \\
\mathbf{0 . 0 2 9}\end{array}$ & $\begin{array}{r}\mathbf{0 . 0 3 1} \\
\mathbf{0 . 0 1 9}\end{array}$ \\
\hline Average Salary & + & \begin{tabular}{r|}
0.001 \\
0.025
\end{tabular} & \begin{tabular}{r|}
0.001 \\
0.083
\end{tabular} & \begin{tabular}{r|}
0.001 \\
0.098
\end{tabular} & & $\begin{array}{r}0.001 \\
0.026\end{array}$ \\
\hline ROA & - & $\begin{array}{r}-0.048 \\
0.405\end{array}$ & $\begin{array}{r}-0.152 \\
0.108\end{array}$ & $\begin{array}{r}-0.012 \\
0.823\end{array}$ & $\begin{array}{r}-0.047 \\
0.478\end{array}$ & \\
\hline Labor/sales & + & $\begin{array}{r}0.147 \\
0.001\end{array}$ & \begin{tabular}{r|}
0.143 \\
0.001
\end{tabular} & $\begin{array}{r}0.165 \\
0.001\end{array}$ & $\begin{array}{r}0.195 \\
0.001\end{array}$ & $\begin{array}{r}0.151 \\
0.001\end{array}$ \\
\hline Log(assets) & - & $\begin{array}{r}-0.005 \\
0.002\end{array}$ & $\begin{array}{r}-0.009 \\
0.001\end{array}$ & & $\begin{array}{r}-0.005 \\
0.013\end{array}$ & $\begin{array}{r}-0.005 \\
0.003\end{array}$ \\
\hline Concentration & - & $\begin{array}{r}-0.015 \\
0.382\end{array}$ & $\begin{array}{r}-0.017 \\
0.541\end{array}$ & \begin{tabular}{r|}
-0.01 \\
0.58
\end{tabular} & $\begin{array}{r}-0.012 \\
0.549\end{array}$ & $\begin{array}{r}-0.017 \\
0.301\end{array}$ \\
\hline $\mathbf{N}$ & & 163 & 209 & 163 & 165 & 163 \\
\hline $\mathbf{R}^{2}$ & & $\begin{array}{r}0.346 \\
0.001\end{array}$ & $\begin{array}{r}0.253 \\
0.001\end{array}$ & $\begin{array}{r}0.305 \\
0.001\end{array}$ & \begin{tabular}{r|}
0.336 \\
0.001
\end{tabular} & $\begin{array}{r}0.343 \\
0.001\end{array}$ \\
\hline
\end{tabular}

Notes:

1. The table reports regression results where the dependent variable is the ratio of human capital asset to market value of equity.

2. Variable definitions are available in notes to table 4.

3. Table entries are the coefficients above, and significance levels below.

4. Bolded entries represent significance levels below $10 \%$. 